Document downloaded from:

http://hdl.handle.net/10251/46560

This paper must be cited as:

Bouzas Blanco, A.; Aguado García, D.; Martí Ortega, N.; Pastor, J.; Herraez, R.; Campins, P.; Seco Torrecillas, A. (2011). Alkylphenols and polycyclic aromatic hydrocarbons in eastern Mediterranean Spanish coastal marine bivalves. Environmental Monitoring and Assessment. 176(1-4):169-181. doi:10.1007/s10661-010-1574-5.

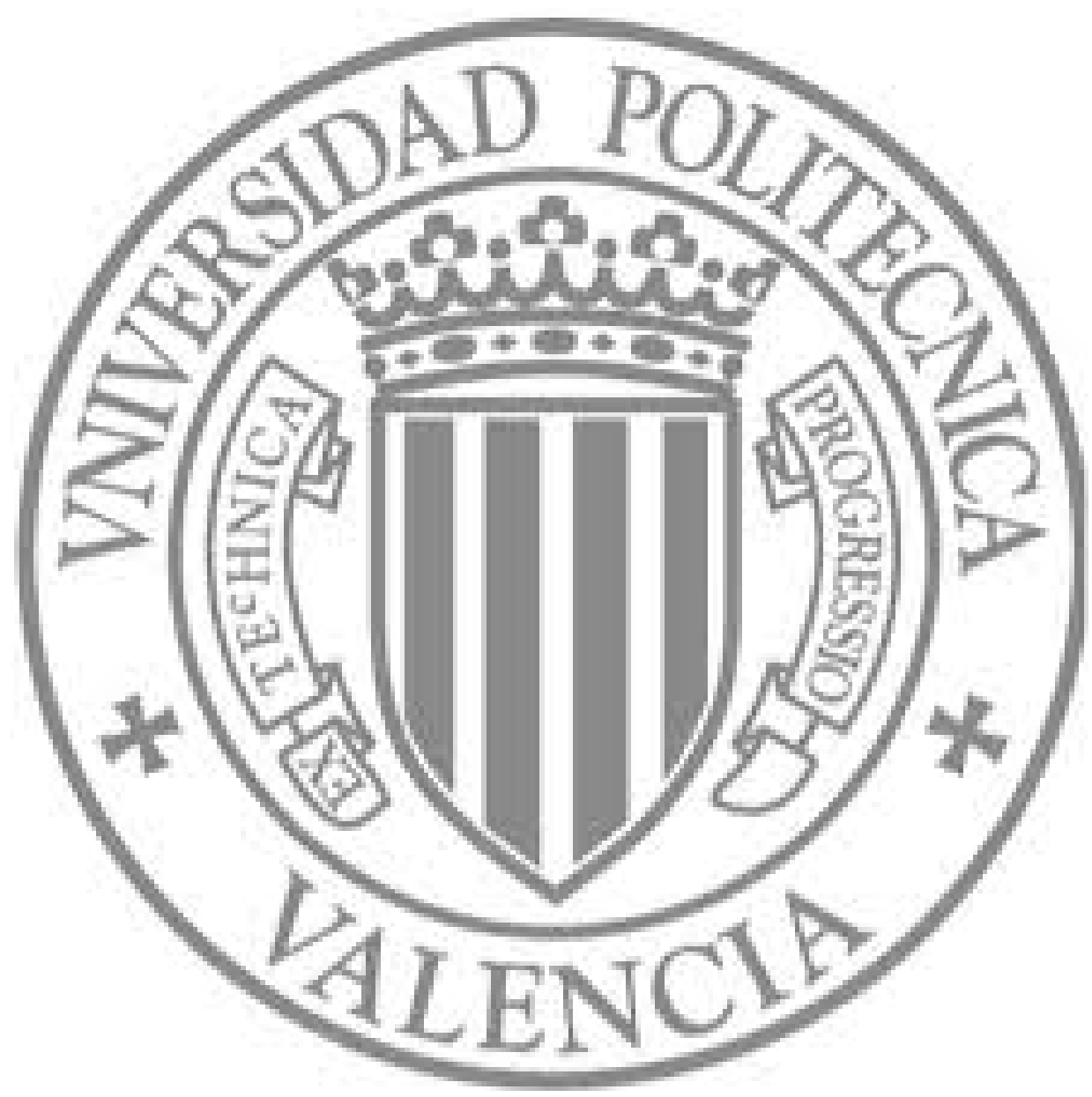

The final publication is available at

http://dx.doi.org/10.1007/s10661-010-1574-5

Copyright

Springer Verlag (Germany) 


\title{
Alkylphenols and Polycyclic Aromatic Hydrocarbons in eastern Mediterranean Spanish coastal marine bivalves.
}

\author{
Alberto Bouzas ${ }^{\mathrm{a}}$, Daniel Aguado ${ }^{\mathrm{b},}$, Nuria Martía ${ }^{\mathrm{a}}$, José Manuel Pastor ${ }^{\mathrm{a}}$, Rosa Herráez ${ }^{\mathrm{c}}$, Pilar Campins ${ }^{\mathrm{c}}$, \\ Aurora $\mathrm{Seco}^{\mathrm{a}}$

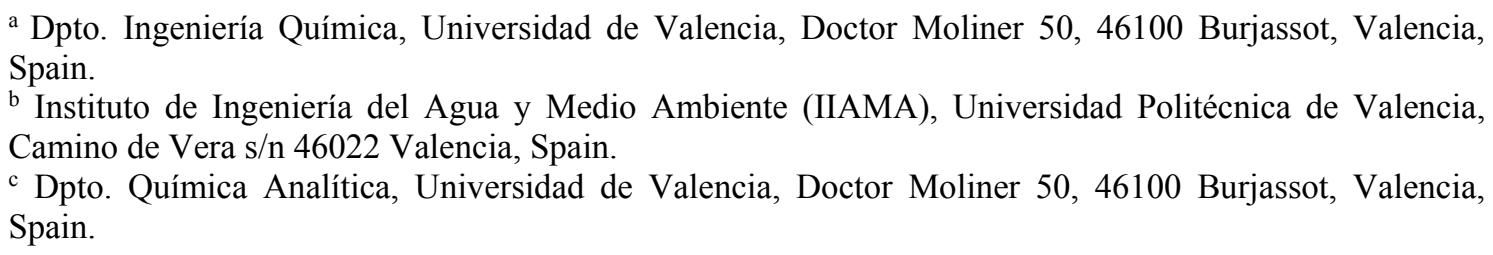

\begin{abstract}
This paper reports the first results on alkylphenol pollution in edible bivalves from the Spanish coast. Two sampling campaigns (July 2006 and July 2007) were carried out to determine the concentration of nonylphenol (NP), octylphenol (OP) and eight Polycyclic Aromatic Hydrocarbons (PAHs) in wild mussels (Mytilus Galloprovincialys) and clams (Donax trunculus) at 14 sampling sites along the eastern Mediterranean Spanish coast. The results show that NP is the predominant alkylphenol, being the port of Valencia the most polluted area (up to $147 \mu \mathrm{g} / \mathrm{kg}$ wet weight in clams). Moving away from the ports the concentration of NP in bivalves decreased. OP concentration was below its detection limit in most of the studied areas and its maximum concentration $(6 \mu \mathrm{g} / \mathrm{kg} \mathrm{w} . \mathrm{w}$.) was measured in clams from the port of Sagunto. The presence of low levels of PAHs was observed in most of the studied areas. The total PAHs concentration (i.e. sum of the 8 measured PAHs) achieved a maximum value of $10.09 \mu \mathrm{g} / \mathrm{kg} \mathrm{W}$.w. in the north coast of Valencia city. The distribution pattern of the individual PAHs showed that both pollution sources petrogenic and pyrolytic were present in the sampled areas. Fluoranthene was the most abundant PAH in mussels while benzo(b)fluoranthene in clams. The maximum concentration of $10 \mu \mathrm{g} / \mathrm{kg} \mathrm{w}$.w. for benzo(a)pyrene established by the European Commission was never reached, indeed sampled bivalves showed concentrations 10 times lower than this reference value. Thus, they can be considered safe for human consumption. Despite the low contamination levels, the results show an overall pollution of bivalves by alkylphenol and PAHs as well as an increment in the number of polluted areas from 2006 to 2007. Thus, periodical sampling campaigns should be carried out to monitor the long-term tendency of these toxic and persistent pollutants.
\end{abstract}

\section{Keywords}

Alkylphenols; Bivalves; Coastal waters; Endocrine Disruptors; Priority pollutants; Polycyclic aromatic hydrocarbons (PAHs).

\section{Introduction}

Monitoring pollution in marine environment can be carried out by measuring pollutant concentrations in bivalves (Goldberg and Bertine, 2000; Solé et al., 2000). The use of bivalve molluscs as sentinel organisms (biomonitors) of marine pollution is due to their ability to accumulate contaminants, their limited capacity for metabolizing them and their resistance to a wide range of pollutant levels (Francioni et al., 2007; Nesto et al., 2007). These organisms are able to bioaccumulate transient pollution present in the water column that sometimes is not recorded in the sediments (Baumard et al., 1999), being in these cases better pollution indicators (Barreira et al., 2007). Moreover, analysing the pollution content in bivalve tissues, where the contaminants are accumulated to noticeably higher concentrations than those in the water, provides information on the fraction of environmental water pollution bioavailable to aquatic organisms (Solé et al., 2000; Baumard et al., 1999). 
Among the widespread pollutants in coastal waters are the alkylphenol polyethoxylates (APnEO) and the polycyclic aromatic hydrocarbons (PAHs). Both pollutant classes present low solubility, high hydrophobicity, high toxicity and high persistence in the environment (Baumard et al., 1999; Isobe et al., 2001; Soares et al., 2008). Due to their hydrophobic character, these compounds rapidly tend to become associated with particles and end up in the sediments which act as a sink for them (Baumard et al., 1999; David et al., 2009; Antizar-Ladislao, 2009).

APnEO are commercially important surfactants with industrial, agricultural, and domestic applications. Nonylphenol polyethoxylates (NPnEO) account for about $80 \%$ of APnEO, and octylphenol polyethoxylates (OPnEO) accounts for most of the remaining 20\% (Isobe et al., 2001). Due to the extensive use of APnEO, they reach the wastewater treatment works in substantial amounts where they are incompletely degraded to alkylphenols (APs) such as nonylphenol (NP) and octylphenol (OP). For this reason, the main source of NP and OP in surface waters is the discharge of municipal and industrial wastewater treatment plants (Soares et al., 2008; Navarro et al., 2009). The impacts of these pollutants (NP and OP) in the environment have been found to include estrogenic effects in aquatic organisms as well as in mammals and birds. APs have been detected in sediment, water and aquatic organisms (Isobe et al., 2001; Senthil Kumar et al., 2008). The interest in their fate and environmental distribution has increased as consequence of their potential effects as endocrine disruptors and their extensive use and applications.

The presence of PAHs in the environment has raised special concern due to their carcinogenic and mutagenic activity on living organisms (White, 1986; Binelli and Provini, 2003). PAHs released into the environment are due to natural processes and anthropogenic sources such as waste incineration, coal gasification and accidental oil spills (Asikainen et al., 2002; Law et al., 2002; Koh et al., 2004). Different authors have reported the presence of PAHs in waters, marine organisms and sediments (Senthil Kumar et al., 2008; Massara Paletto et al., 2008; Francioni et al., 2007; Boscolo et al., 2007).

Due to the adverse effects of APs and PAHs on the environment and their extensive use, the European Union, have included these pollutants in the list of priority hazardous substances for surface waters in the Water Framework Directive 2000/60/EC (WFD) (EC, 2000). Although Environmental Quality Standards (EQS) for priority pollutants in surface waters have been proposed in order to achieve "good surface water chemical status", no limits have been established for the concentration of priority pollutants in biota. However, for the PAHs content in biota several guidelines exist: the commission regulation (EC, 2005) which stipulates a maximum concentration of $10 \mu \mathrm{g} / \mathrm{kg} \mathrm{w} . \mathrm{w}$. of benzo(a)pyrene in edible molluscs (this regulation also limits the benzo(a)pyrene concentration in other alimentary products), the OPSAR Commission which has developed eco-toxicological assessment criteria (i.e., concentrations levels above which concern is indicated) for different PAHs in fish and mussels (OPSAR, 2000), and the Oregon Health Division which has derived risk-based criteria for PAHs (Gilroy, 2000) assessing the risk in terms of benzo(a)pyrene equivalents.

Since the occurrence and abundance of APs and PAHs in aquatic environments represent a risk to aquatic organisms and ultimately to humans (through fish and shellfish consumption), there is a need for their determination and quantification around 
the world (Antizar-Ladislao, 2009). Many studies have been carried out to determine the PAHs distribution in marine organisms in different geographical areas. However, as pointed out by David et al. (2009) the presence of AP in coastal and marine ecosystems is not as well documented as in freshwater ecosystems and, therefore, accurate data are needed to assess AP pollution of marine environments.

There is no information available on the occurrence of APs in Spanish coastal marine bivalves and the number of studies focused on PAHs in eastern Spanish coastal marine bivalves is limited. Thus, the aim of this work is to study the distribution of NP, OP and several PAHs along the eastern Mediterranean Spanish coast using mussels (Mytilus Galloprovincialys) and clams (Donax trunculus) as biomonitors. Both bivalves have been chosen because they have desirable characteristic of potential biomonitors and are widely distributed along the Mediterranean coastal waters. Moreover, these marine organisms present different location along the coast: mussels are located on rocks or breakwaters at the air-water interface, whereas clams growth on shallow waters of sandy beaches in close contact with the sediment. Therefore, Mytilus Galloprovincialys which filters large quantities of water is mainly exposed to the soluble fraction of the pollutants whereas Donax trunculus is exposed to soluble and particle-associated toxic contaminants. In this study, multivariate statistical projection techniques for analysing the data obtained have been applied in order to identify the most polluted areas and the relationships among the contaminants measured.

\section{Materials and methods}

\subsection{Study area and sampling procedure}

Bivalves were collected at 14 sampling sites along the eastern Mediterranean Spanish coast covering different water bodies from the Comunidad Valenciana (see Figure 1). It is an economical and industrial developed area with a population around 5 million people, which represents approximately $11 \%$ of the total Spanish population. Therefore, the coastal waters from this region $(470 \mathrm{~km}$. of coastline) are influenced by human activities and pressures, such as urban development, industries and important commercial harbours.

Along the coast of the Comunidad Valenciana, 24 "water bodies" were defined (Figure 1). 18 of these water bodies were classified as coastal waters whereas 6 of them were classified as heavily modified water bodies (i.e., harbours). Within each water body mussels (Mytilus Galloprovincialys) and clams (Donax trunculus) were searched at two different sampling points to obtain a representative sample of each water body. However, due to the geographical and geological characteristics of some of the studied areas as well as to the human harvest of bivalves, it was impossible to obtain enough quantity of bivalves in some areas. Therefore, it was only possible to collect representative samples in 14 water bodies (10 coastal waters and 4 heavily modified waters). Moreover, in some of these water bodies it was not feasible to collect bivalves from the two sampling points. The corresponding results are included in this paper.

Two sampling campaigns were carried out: July 2006 and July 2007. Clams were collected in shallow waters of sandy beaches using a rake. Thus, no samples of clams were available from rocky beaches. Mussels were collected by hand from the rocky 
areas or breakwaters. Efforts were made to obtain specimens of similar size at all sampling sites (approximate length: mussels $34 \pm 4.7 \mathrm{~mm}$; clams $21 \pm 3.5 \mathrm{~mm}$ ). In total 76 samples of marine invertebrates were collected including both sampling campaigns. At each sample site, plastic bottles, previously washed with $\mathrm{HNO}_{3}$, were completely filled with mussels and clams. $2 \mathrm{~L}$ volume bottles were filled with mussels (in average 40 specimens per sample). For clams $0.5 \mathrm{~L}$ volume bottles were used (in average 30 specimens per sample). Bottles used to storage the samples were quickly transported to the laboratory in a fridge and once in the lab, bivalve edible tissues were removed from the shells, homogenized and frozen. Finally, samples were lyophilised.

\subsection{Analytical methods}

A new method based on miniaturized matrix solid-PAHse dispersion (MSPD) with acetonitrile was developed and used to extract the analytes from the samples $(0.1 \mathrm{~g})$ (Campins et al., 2008). Each bivalve sample was analysed for its content of NP, OP and eight PAHs (including those especially recommended by the WFD): anthracene (Ant), benzo(a)pyrene $(\mathrm{BaP})$, benzo(g,h,i)perylene $(\mathrm{BgP})$, benzo(b)fluoranthene $(\mathrm{BbF})$, benzo(k)fluoranthene $(\mathrm{BkF})$, dibenzo(a,h)anthracene (DBA), fluoranthene (Flu) and benzo(a)anthracene (BaA). The PAHs were analysed by conventional liquid chromatography with fluorescence detection (LC-FD) using in-tube solid-PAHse microextraction (ITSPME). The concentration of NP and OP was determined by gas chromatography/mass spectrometry (GC-MS) using solid-PAHse microextraction. The detection limit (in $\mu \mathrm{g} / \mathrm{kg}$ dry weight) for each pollutant was: 35.0 for NP; 0.35 for OP; 0.05 for Ant, 0.3 for $\mathrm{BaP}, \mathrm{BgP}, \mathrm{BbF}, \mathrm{BkF}, \mathrm{DBA}$ and Flu; 0.2 for $\mathrm{BaA}$. The limits of detection (LOD) were calculated by spiking a lyophilised biota sample in which that particular pollutant was absent with a known amount of a standard solution containing that compound. The LODs were the concentrations that resulted in signal-to-noise ratios of 3 .

Results are reported as $\mu \mathrm{g} / \mathrm{kg}$ on wet weight basis (w.w.), as the guidelines and limits for dangerous substances in food for human consumption are normally expressed in wet weight basis. To enable comparison with data from other investigations, the reported values can be converted taking into account the measured humidity of the specimens, which was $80 \%$ for mussels and $75 \%$ for clams.

\subsection{Statistical analysis}

Principal Component Analysis (PCA) was applied on all the chemical variables analysed in both mussels and clams, to provide a graphical summary of the relevant information contained in the data tables. PCA is a multivariate statistical projection method used to compress high-dimensional data into a lower-dimensional space, thus, making data more comprehensible by retaining and highlighting essential information (e.g., relationships among the variables and observations, patterns, trends,...). The presentation of the modelling results is graphically-oriented, thus, the essential information in the data can be interpreted from graphical displays of the scores and weights. In mathematical terms, PCA decompose the data matrix $\mathbf{X}$ of size $[\mathrm{m}, \mathrm{n}]$ into

bilinear terms according to $\mathbf{X}=\sum_{a=1}^{A} \mathbf{t}_{a} \mathbf{p}_{a}^{T}+\mathbf{E}$, where $\mathbf{t}_{a}$ are the latent variables, $\mathbf{p}_{a}$ the corresponding loading vectors, $\mathbf{E}$ is the residual matrix, and $A$ is the number of significant components retained. When the numerous collected data are highly 
correlated, it results that $A<<\mathrm{n}$, and therefore, using PCA, high degree of data compression is achieved. Further PCA description and the detailed mathematical founding can be found elsewhere (e.g., Jackson, 2003).

SIMCA-P 9.0 software (Umetrics, Umea, Sweden) was used for the multivariate analysis.

\section{Results and discussion}

\subsection{Alkylphenols results in mussels and clams}

The results (mean concentration and range from both sampling campaigns) for NP and OP in samples of mussels and clams collected at the different water bodies are shown in Table 1. Two parameters have been also included in this table: \%FREC which is the frequency of occurrence (i.e., the percentage of the studied areas in which the pollutant is detected), and \%INC which is the percentage of the studied areas where an increase of the contaminant took place from 2006 to 2007.

As can be observed, NP is the predominant alkylphenol in both types of bivalves, showing higher concentration, higher frequency of occurrence (\%FREC) and higher increase in affected areas (\%INC) than OP. Concentrations of NP in mussels and clams vary from $<7-120 \mu \mathrm{g} / \mathrm{kg} \mathrm{w}$.w. and $<5-147 \mu \mathrm{g} / \mathrm{kg} \mathrm{w}$.w., respectively. OP was below its detection limit $(0.7 \mu \mathrm{g} / \mathrm{kg} \mathrm{w} . \mathrm{w}$. and $0.5 \mu \mathrm{g} / \mathrm{kg} \mathrm{W.w}$. for mussels and clams, respectively) in most of the studied areas being its concentration in the interval $<0.7-2.5 \mu \mathrm{g} / \mathrm{kg} \mathrm{w}$.w. and $<0.5-6.0 \mu \mathrm{g} / \mathrm{kg}$ w.w. in mussel and clam samples, respectively. The significant presence of NP in both bivalves reflects an exposure to alkylphenolic surfactants (APnEO) from the discharges of industries and urban areas through wastewater treatment plants (WWTPs). NP appears during degradation in WWTPs of these widely used APnEO surfactants. Despite that some studies indicate that NP is more efficiently removed in WWTPs than OP (Isobe et al., 2001), the higher presence and abundance of NP than OP in both bivalves observed in this study, can be explained by their different hydrophobicity as well as the fact that commercial alkylphenols formed by nonylphenol polyethoxylates are much more used than those formed by octylphenol polyethoxylates. The log Kow (octanol-water partition coefficient) is 4.5 for NP and 4.1 for OP (Isobe et al., 2001). This indicates a greater tendency of NP respect to OP to bioaccumulate in bivalve organic tissues and/or sediments. Other researches have also obtained significantly higher NP concentrations than OP in marine organisms such as oysters and mussels (Senthil Kumar et al., 2008; Ferrara et al., 2001) and sediments (Isobe et al., 2001), proving a higher NP presence in the environment.

The most AP polluted area is the port of Valencia (zone 0081) followed by the nearby zones (007 and 008) which correspond to high industrialised zones. The port of Castellon (zone 0041) is also significantly affected by AP pollution, but in this case due to NP only in clams. In general, moving away from the ports the concentration of AP in bivalves decreased.

The NP levels found in bivalves from the most polluted zones of the coastal waters of Comunidad Valenciana are lower than those reported by Ferrara et al. (2001) in edible bivalves of the Adriatic Sea (254-265 $\mu \mathrm{g} / \mathrm{kg} \mathrm{w} . w$. in mussels and 243-252 $\mu \mathrm{g} / \mathrm{kg} \mathrm{w}$.w. in clams). Li et al. (2008) reported NP values in mussels from the Massan Bay (Korea) up 
to $290 \mu \mathrm{g} / \mathrm{kg}$ d.w., which are lower than the maximum value found in this study (120 $\mu \mathrm{g} / \mathrm{kg}$ w.w. which would be $600 \mu \mathrm{g} / \mathrm{kg}$ d.w. considering the measured water content) but similar to the average pollution level found along the Mediterranean coast studied $(200 \mu \mathrm{g} / \mathrm{kg} \mathrm{d.w.).} \mathrm{Isobe} \mathrm{et} \mathrm{al.} \mathrm{(2007)} \mathrm{carried} \mathrm{out} \mathrm{an} \mathrm{extensive} \mathrm{monitoring} \mathrm{survey} \mathrm{in}$ South and Southeast Asia coasts, reporting NP concentrations in mussels from $18 \mu \mathrm{g} / \mathrm{kg}$ d.w. in Malaysia to $1347 \mu \mathrm{g} / \mathrm{kg}$ d.w. in Tokyo Bay. The rapid population growth and drastic industrialization in South and Southeast Asia during the last decades, together with the no regulation of alkylphenol compounds in these countries, explain the significant NP concentrations observed especially in high industrialised regions.

The maximum OP concentrations measured in this study ( $<$ LOD-2.5 and $<$ LOD-6.0 $\mu \mathrm{g} / \mathrm{kg} \mathrm{w}$.w. in mussel and clam samples, respectively) are lower than those obtained by Ferrara et al. (2001) for mussels from the Adriatic Sea (4.4-4.9 $\mu \mathrm{g} / \mathrm{kg}$ w.w.) but higher than those measured in clams from the same sea $(2.7-2.8 \mu \mathrm{g} / \mathrm{kg}$ w.w.). Isobe et al. (2007) reported higher OP values in the mussels from different Asiatic countries (up to $54.4 \mu \mathrm{g} / \mathrm{kg}$ d.w. in Tokyo Bay) than those found in this study $(<\mathrm{LOD}-12.5 \mu \mathrm{g} / \mathrm{kg} \mathrm{d}$.w. in mussels).

Due to the adverse effects of alkylphenol polyethoxylates, some countries have restricted their use. The European Union has included nonylphenol and its ethoxylates in the Water Framework Directive (WFD) as priority hazardous substances. According to the WFD, Member States should implement measures with the aim of ceasing or phasing out emissions, discharges and losses of these priority hazardous substances. However, other countries such as China, India and several South American countries extensively use and produce nonylphenolic compounds without restrictions (Soares et al., 2008). Due to their limited elimination in existing WWTPs and that upgrading these plants with advanced technologies (UV treatment and ozonation, activated carbon filters...) would imply high economical costs, the best alternative seems to be ceasing the production and use of nonylphenol ethoxylates and replace them with other environmentally safer surfactants as in Europe, Canada and Japan.

\subsection{PAHs results in mussels and clams}

The mean concentration and range for each individual $\mathrm{PAH}$ in mussels and clams as well as the parameters \%FREC and \%INC are shown in Table 2. It can be seen in this table that Ant presented the lowest mean concentration in all the sampled water bodies for both, mussels and clams. The highest concentrations were found for Flu, DaA and $\mathrm{BbF}$. The results show that most of the coastal waters of Comunidad Valenciana are affected by the presence of low levels of PAHs. The higher frequency values obtained in clams than in mussels are due to the absence of clam samples in the north part of Comunidad Valenciana (zones 002 to 005). Thus, these zones can not be considered for the calculation of the \%FREC parameter in clams. The less frequent $\mathrm{PAH}$ is $\mathrm{BaP}$ affecting the mussels in $53.8 \%$ of the studied areas and the clams in $90 \%$ of the areas where clam samples were available. Regarding the increase factor (\%INC), the results obtained show a high percentage of areas where PAHs concentration in bivalves have increased. The compounds that have increased in a greater extent from 2006 to 2007 are: $\mathrm{BbF}, \mathrm{BkF}, \mathrm{DaA}$ and $\mathrm{BaA}$. According to these results, it seems to be necessary to carry out periodical sampling campaigns to monitor and assess the long-term tendency of these compounds as recommended by the Water Framework Directive. 
In order to clearly identify the most PAH polluted areas along the coastal waters of Comunidad Valenciana, the mean concentration of both sampling campaigns for the total PAHs (sum of the 8 measured PAHs) for each bivalve in each water body is shown in Figure 2. Total PAH concentrations in mussels and clams vary from $0.21-8.95 \mu \mathrm{g} / \mathrm{kg}$ w.w. and 0.43-10.09 $\mu \mathrm{g} / \mathrm{kg}$ w.w., respectively. As can be observed (Figure 2) the most polluted areas by PAHs are the port of Sagunto and the north coast of Valencia (areas 006 and 007).

To asses the PAHs pattern in the most polluted area (007) for both marine organisms, the relative concentration of each PAH calculated as the percentage of each PAH respect to the total PAHs is shown in Figure 3a. As this Figure shows, the highest molecular weight (MW) compounds (DBA (hexa-aromatic) and BgP (penta-aromatic)), which are those with the highest octanol-water partition coefficient (Kow) are accumulated in a greater extent in clams than in mussels. These heavier compounds are preferentially associated with suspended particles that settle and, thus, will be the predominant PAH in the sediment. Since clams are located close to the sediment they are more exposed to these high MW compounds than mussels which are located at the air-water interface. This tendency is not observed for the other 5-ring compounds analysed with lower molecular weight ( $\mathrm{BaP}, \mathrm{BbF}$ and $\mathrm{BkF}$ ) which are accumulated in similar proportions in both bivalves. The tetra-aromatic compounds (Flu and $\mathrm{BaA}$ ) which are more water soluble (especially Flu) and therefore more readily available in the water column are mainly accumulated in mussel tissues. The only 3-ring compound analysed (Ant) shows very low concentrations and similar pattern in both marine organisms.

With the aim of assessing the possible PAHs pollution source, the information contained in Figure 3 a can be summarised obtaining the relative abundance of low molecular weight (LMW) and high molecular weight (HMW) compounds in bivalves' tissue. This is shown in Figure $3 \mathrm{~b}$ which displays the ratio of the sum of the concentrations of LMW PAHs to the sum of the concentrations of all measured PAHs, and the ratio of sum of the concentrations of HMW compounds to the of sum of the concentrations of all measured PAHs. Pyrolytic activities (i.e., fossil fuel combustion, waste incineration...) produce HMW PAHs (benzo(a)anthracene, 5- and 6-ring compounds) whereas petrogenic activities (i.e., oil spills, refinery products...) generate LMW PAHs (3-ring compounds and fluoranthene). Thus, Figure 3b suggests that both pollution sources are present in this water body (area 007) although the pyrolytic input to a significantly greater extent. Similar contamination patterns have been observed in bivalves from the remaining water bodies sampled (Figures not shown) except in harbours where the contribution of petrogenic inputs increases up to the same extent of the pyrolytic contribution.

The total PAH concentration obtained in the present study (ranging from 1.1 to 44.5 $\mu \mathrm{g} / \mathrm{kg}$ d.w. in mussels and from 2.9 to $67.3 \mu \mathrm{g} / \mathrm{kg} \mathrm{d}$.w. in clams, considering the water content of the sampled bivalves), exhibit pollution levels characteristics of low contaminated areas (Baumard et al., 1998). Comparing the same 8 PAHs analysed in this study (Ant, BaP, BgP, BbF, BkF, DBA, Flu y BaA) with other investigations, the total PAHs concentration is significantly lower than those recently reported by M.A. Khairy et al. (2009) in mussels from Abu Qir Bay, Egypt (190-1480 $\mu \mathrm{g} / \mathrm{kg}$ d.w. in mussels Mactra corallina and 11-2216 $\mu \mathrm{g} / \mathrm{kg}$ d.w. in mussels Tapes decussate), slightly lower than those found by Palma-Flemming et al (2004) in mussels from Chile (65-70 
$\mu \mathrm{g} / \mathrm{kg}$ d.w.) and similar to that reported by Grandby and Spill (1999) in the Danish coasts $(10.9 \mu \mathrm{g} / \mathrm{kg}$ w.w.). Other reported values from Spanish coasts show similar concentrations in bivalves from the coastal waters of Barcelona $(23.4 \mu \mathrm{g} / \mathrm{kg}$ d.w.; Baumard et al., 1999) but lower than those from the Barcelona inner harbour (106.1 $\mu \mathrm{g} / \mathrm{kg}$ d.w.; Baumard et al., 1999). Mussels collected on the Cantabrian coasts (before the Prestige oil spill) showed in several zones concentrations below $50 \mu \mathrm{g} / \mathrm{kg}$ d.w. which according to Soriano et al. (2006) can be considered the background pollution in the region while in other zones values above $200 \mu \mathrm{g} / \mathrm{kg} \mathrm{d.w}$. were found which according to these authors reflected the vicinity of certain urban or industrial hydrocarbons sources.

Regarding the possible human health implications of the presence of PAHs in edible bivalves, the European Commission has set a maximum concentration of $10 \mu \mathrm{g} / \mathrm{kg} \mathrm{w} . \mathrm{w}$. (referred to benzo(a)pyrene) (EC, 2005). Bivalves from the sampled zones of the eastern Mediterranean Spanish coast show concentrations of benzo(a)pyrene more than 10 times lower than this reference value. Moreover, the Ecotoxicological Assessment Criteria developed by the OPSAR for PAHs in mussels (Table 3) was never surpassed. The risk evaluation criteria developed by the Oregon Health Division (Gilroy, 2000) consists in converting the carcinogenic PAHs to total benzo(a)pyrene equivalents (in $\mu \mathrm{g} / \mathrm{kg} \mathrm{w.w.).} \mathrm{For} \mathrm{a} \mathrm{given} \mathrm{sample,} \mathrm{this} \mathrm{is} \mathrm{done} \mathrm{by} \mathrm{multiplying} \mathrm{the} \mathrm{concentration} \mathrm{of} \mathrm{each}$ $\mathrm{PAH}$ in the sample by the corresponding equivalence factor (Table 3). If the BaP equivalents of a given sample are lower than $10 \mu \mathrm{g} / \mathrm{kg} \mathrm{w} . \mathrm{w}$. , the shellfish can be considered safe for human consumption, and if greater than $45 \mu \mathrm{g} / \mathrm{kg}$ w.w. unsafe. According to these criteria, in this study all the samples of edible bivalves can be considered safe and acceptable for human consumption since in the most PAH polluted zone, the maximum value for the sum of all PAHs was $10.09 \mu \mathrm{g} / \mathrm{kg} \mathrm{w}$.w. Applying the equivalence factors of Table 3 to this area, the $\mathrm{BaP}$ equivalents would result in $3.71 \mu \mathrm{g} / \mathrm{kg} \mathrm{w} . \mathrm{w}$ which is considerably lower than the reference value of $10 \mu \mathrm{g} / \mathrm{kg} \mathrm{w} . \mathrm{w}$. for safe shellfish.

\subsection{Statistical analysis}

Finally, the alkylphenols and PAHs results for both, mussels and clams, have been summarised carrying out a PCA on a data set composed by the mean values shown in Tables 1 and 2. A PCA-model was fitted to the pre-processed data (mean-centred and scaled to unit variance). Two principal components were retained in the PCA model, explaining $67.3 \%$ and $11.5 \%$ of the total variance, respectively. The results of the fitted model are graphically displayed in Figures $4 \mathrm{a}$ and $4 \mathrm{c}$. The score plot (Figure 4a) shows how the different areas relate to each other (i.e., similar areas -in terms of the pollutants analyzed- are close in the plot). The loading plot (Figure 4c) shows the relationship among the variables and indicate which variables are responsible for the patterns observed in the corresponding score plot. It can be seen that the first component is mainly related to the PAHs, exhibiting all of them a clear positive correlation. This positive correlation indicates that most of the analysed PAHs are present in those areas polluted by PAHs. As previously explained, this is due to the fact that both pollution sources (pyrolytic and petrogenic) are present along the studied area. The second component contains the information related to the alkylphenols.

In Figure 4a it can be seen that areas 006, 007 (both areas in the north of Valencia city) and 017 (in the south of the Mediterranean coast sampled) are quite far from the rest. 
From the loading plot (Figure 4c) it can be concluded that the separation of areas 006 and 007 is mainly due to their high PAHs concentration, although the OP concentration is also important in clams from area 006 compared with the others, whereas the separation of area 017 is mainly due to its high OP concentration in comparison with the OP levels found in all the remaining areas.

In order to closely examine the main cluster, another PCA was conducted excluding areas 006, 007 and 017. Two components were retained, explaining $62.7 \%$ and $17.2 \%$ of the total variance, respectively. The loading plot (Figure 4d) shows that the first component is again associated to the PAHs, whereas the second one to the alkylphenols. From Figures $4 \mathrm{~b}$ and $4 \mathrm{~d}$, it can be seen that area 0081 (Port of Valencia) is far from the rest due to the high presence of alkylphenols, whereas areas 009, 010 and 0101 due to their PAHs concentration. Regarding the least polluted areas, they are located in the plot in opposite direction to the pollutants, i.e., left-hand for low levels of PAHs: mussels from areas 001, 002, 003 and clams from area 041; downwards for relative low levels of alkylphenols: clams from areas 010 and 0101.

\section{Conclusions}

To the knowledge of the authors, this is the first time that alkylphenol pollution levels in edible bivalves from the Spanish coast are reported. In this study, nonylphenol, octylphenol and eight Polycyclic Aromatic Hydrocarbons were determined in mussels (Mytilus Galloprovincialys) and clams (Donax trunculus) at 14 sampling sites along the eastern Mediterranean Spanish coast.

Considering the results on both marine invertebrates, overall pollution by alkylphenol has been observed in all the studied areas. The results also show that NP is the predominant alkylphenol along the coast, being the Port of Valencia the most polluted area. The OP concentration was below its detection limit in most of the studied areas.

Regarding the PAH pollution, the presence of low levels of PAHs was observed in most of the studied areas. The maximum total PAH concentration (i.e. sum of the 8 measured PAHs) was $10.09 \mu \mathrm{g} / \mathrm{kg} \mathrm{ww}$, achieved in the north coast of Valencia city (area 007). Fluoranthene was the most abundant PAH in mussels while benzo(b)fluoranthene in clams. Bivalves from the eastern Mediterranean Spanish coastal waters can be considered safe for human consumption since their concentrations were more than 10 times lower than the maximum level established.

Despite the low contamination levels, the results show an overall pollution of bivalves by alkylphenol and PAHs as well as an increment in the number of polluted areas from 2006 to 2007. Therefore, further research is required to monitor and assess the longterm tendency of these toxic and persistent compounds as recommended by the Water Framework Directive.

\section{Acknowledgements}

Financial support from Conselleria de Medio Ambiente, Agua, Urbanismo y Vivienda de la Generalitat Valenciana (Application of Water Framework Directive 2000/60/EC 
on endocrine disruptors and priority substances in coastal areas in the Comunidad Valenciana) is gratefully acknowledged.

\section{References}

Antizar-Ladislao, B., 2009. Polycyclic aromatic hydrocarbons, polycholirnated biphenyls, phthalates and organotins in northern Atlantic Spain's coastal marine sediments. Journal of Environmental Monitoring, 11, 85-91.

Asikainen, A.H., Kuusisto, M.P., Hiltunen, M.A. and Ruuskanen, J., 2002. Occurrence and destruction of PAHs, PCBs, ClPhs, ClBzs, and PCDD/Fs in ash from gasification of straw. Environmental Science and Technology, 36, 2193-2197.

Barreira, L.A., Mudge, S.M., Bebianno, M.J., 2007. Polycyclic aromatic hydrocarbons in clams Ruditapes decussatus (Linnaeus, 1758). Journal of Environmental Monitoring, 9, 187-198.

Baumard, P., Budzinski, H. and Garrigues, P., 1998. PAHs in Arcachon Bay, France: Origin and biomonitoring of caged organisms. Marine Pollution Bulletin, 36, 577586.

Baumard, P., Budzinski, H. and Garrigues, P., Narbonne, J.F., Burgeot, T., Miche, X. and Bellocq, J., 1999. Polycyclic aromatic hydrocarbon (PAH) burden of mussels (Mytilus sp.) in different marine environments in relation with sediment PAH contamination, and bioavailability. Marine Environmental Research, 47, 415-439.

Binelli, A., Provini, A., 2003. POPs in edible clams from different Italian and European markets and possible human health risk. Marine Pollution Bulletin, 46, 879 -886.

Boscolo, R., Cacciatore, F.and Giovanardi, O., 2007. Polycyclic aromatic hydrocarbons (PAHs) in transplanted Manila clams (Tapes philippinarum) from the Lagoon of Venice as assessed by PAHs/shell weight index: A preliminary study. Marine Pollution Bulletin, 55, 485-493.

Campíns, P., Verdú, J., Sevillano, A., Molins, C. and Herráez, R., 2008. New micromethod combining miniaturized matrix solid-phase dispersion and in-tube invalve solid-phase microextraction for estimating polycyclic aromatic hydrocarbons in bivalves. Journal of Chromatography A, 1211, 13-21.

David, A., Fenet, H., Gomez, E. 2009. Alkylphenols in marine environments: Distribution monitoring strategies and detection considerations. Marine Pollution Bulletin, doi:10.1016/j.marpolbul.2009.04.021.

EC, 2000. Directive 2000/60/EC of the European Parliament and of the Council of 23 October 2000 establishing a framework for Community action in the field of water policy. Off. J. Eur. Comm., L 327, 22.12.2000, p. 1.

EC, 2005. Commission regulation (EC) No 2008/2005 of of 4 February 2005 amending Regulation (EC) No 466/2001 as regards polycyclic aromatic hydrocarbons. Off. J. Eur. Union, L 34, 8.2.2005, p. 3. 
Ferrara, F., Fabietti, F., Delise, M., Piccioli-Bocca, A. and Funari, E., 2001. Alkylphenolic compounds in edible mollusc of the Adriatic Sea (Italy). Environmental Science and Technology, 35, 3109-3112.

Francioni, E., de L.R, Wagener, A., Scofield, A.L., Depledge, M.H. and Cavalier, B., 2007. Evaluation of the mussel Perna perna as a biomonitor of polycyclic aromatic hydrocarbon (PAH) exposure and effects. Marine Pollution Bulletin, 54, 329-338.

Gilroy, D.J., 2000. Derivation of Shellfish harvest reopening criteria following the new Carissa oil spill in Coos Bay, Oregon. Journal of Toxicology and Environmental Health, 60, 317-329.

Goldberg, E.D., Bertine, K.K., 2000. Beyond the Mussel Watch - new directions for monitoring marine. Science of the Total Environment, 247, 165-174.

Grandby, K and Spliid, N.H., 1995. Hydrocarbon and organochlorines in common mussels from the Kattegat and the Belts and their relation to condition indices. Marine Pollution Bulletin, 30, 74-82.

Isobe, T., Nishiyama, H., Nakashima, A. and Takada, H., 2001. Distribution and Behavior of Nonylphenol, Octylphenol, and Nonylphenol Monoethoxylate in Tokyo Metropolitan Area: Their Association with Aquatic Particles and Sedimentary Distributions. Environmental Science and Technology, 35, 1041-1049.

Isobe, T., Takada, H., Kanai, M., Tsutsumi, S., Isobe, K.O., Boonyatumanond, R., Zkaria, M.P., 2007. Distribution of polycyclic aromatic hydrocarbons (PAHs) and phenolic endocrine disrupting chemicals in South and Southeast Asian mussels. Environmental Monitoring Assessment, 135, 423-440

Jackson, J.E., 2003. A User's guide to principal components. John Wiley \& Sons, NJ.

Khairy, M.A., Kolb, M., Mostafa, A.R., EL-Fiky, A., Bahadir, M. (2009). Risk assessment of polycyclic aromatic hydrocarbons in a Mediterranean semiencolsed basin affected by human activities (Abu Qui Bay, Egypt). J.Hazard. Mater., doi:10.1016/j.jhazmat.2009.04.084

Koh, C.H., Khim, J.S., Kannan, K., Villeneuve, D.L., Senthil Kumar, K. and Giesy, J.P., 2004. Polychlorinated dibenzo-p-dioxins (PCDDs), dibenzofurans (PCDFs), biphenyls (PCBs), and polycyclic aromatic hydrocarbons (PAHs) and 2,3,7,8TCDD equivalents (TEQs) in sediment from the Hyeongsan River, Korea. Environmental Pollution, 132, 489-501.

Law, R.J., Kelly, C.A., Baker, K.L., Langford, K.H. and Bartlett, T., 2002. Polycyclic aromatic hydrocarbons in sediments, mussels and crustacea around a former gasworks site in Shoreham-by-Sea, UK. Marine Pollution Bulletin, 44, 903-911.

Li, D., Dong, M., Shim, W.J., Yim, U.H., Hong, S. and Kannan. N., 2008. Distribution characteristics of nonylphenolic chemicals in Masan Bay environments. Korea. Chemosphere, 71, 1162-1172. 
Massara Paletto,V., Commendatore, M.G. and Esteves, J.L., 2008. Hydrocarbon levels in sediments and bivalve mollusks from Bahía Nueva (Patagonia, Argentina): An assessment of probable origin and bioaccumulation factors. Baseline/ Marine Pollution Bulletin, 56, 2082-2105.

Navarro, A., Endo, S., Gocht, T., Barth, J.A.C., Lacorte, S., Barceló, D. and Grathwohl, P., 2009. Sorption of alkylphenols on Ebro River sediments: Comparing isotherms with field observations in river water and sediments. Environmental Pollution, 157, 698-703.

Nesto, N., Romano, S., Moschino, V., Mauri, M. and Da Ros, L., 2007. Bioaccumulation and biomarker responses of trace metals and micro-organic pollutants in mussels and fish from the Lagoon of Venice, Italy. Marine Pollution Bulletin, 55, 469-484.

OSPAR Commision, Quality Status Report 2000. OSPAR, London, 2000.

Palma-Fleming, H., Asencio, A. J., Gutierrez, E. (2004). Polycyclic aromatic hydrocarbons in sediments and mussels of Corral Bay, south central Chile. Journal of Environmental Monitoring, 6, 229-233.

Senthil Kumar, K., Sajwan, K.S., Richardson J.P. and Kannan, K., 2008. Contamination profiles of heavy metals, organochlorine pesticides, polycyclic aromatic hydrocarbons and alkylphenols in sediment and oyster collected from marsh/estuarine Savannah GA, USA. Marine Pollution Bulletin, 56, 136-162.

Solé, M., Porte, C., Barceló, D., Albigés, 2000. Bivalves residue analysis for the assessment of coastal pollution in the Ebro Delta (NW Mediterranean). Marine Pollution Bulletin, 40 (9), 746-753.

Soares, A., Guieysse, B., Jefferson, B., Cartmell E. and Lester, J.N., 2008. Nonylphenol in the environment: A critical review on occurrence, fate, toxicity and treatment in wastewaters. Environmental International, 34, 1033-1049.

Soriano, J.A., Viñas, L., Franco, M.A., González, J.J., Ortiz, L., Bayona, J.M., Albaigés, J., 2006. Spatial and temporal trends of petroleum hydrocarbons in wild mussels from the Galician coast (NW Spain) affected by the Prestige oil spill. Science of the Total Environment 370, 80-90.

White, K. L., 1986. An overview of immunotoxicology and carcinogenic polycyclic aromatic hydrocarbons. J. Environ. Sci. Health Pt. C-Environ. Carcinog. Ecotoxicol. Rev., 2, 163-202. 
Table 1. Concentrations of NP and OP in mussel and clam samples ( $\mu \mathrm{g} / \mathrm{kg} w w)$. Mean value, $\min -\max$ in brackets, n.a.: Samples Not Available, LOD: detection limit. \%FREC: percentage of the studied areas in which the pollutant is detected, \%INC: percentage of the studied areas where an increase of the contaminant took place from 2006 to 2007.

\begin{tabular}{|c|c|c|c|c|c|c|c|c|}
\hline \multirow{3}{*}{$\frac{\text { Water body }}{001}$} & \multicolumn{4}{|c|}{ Mussels } & \multicolumn{4}{|c|}{ Clams } \\
\hline & \multicolumn{2}{|c|}{ Nonylphenol } & \multicolumn{2}{|c|}{ Octylphenol } & \multicolumn{2}{|c|}{ Nonylphenol } & \multicolumn{2}{|c|}{ Octylphenol } \\
\hline & 20.8 & $(7.0-30.0)$ & $<\mathrm{LOD}$ & & 50.0 & $(30.0-63.0)$ & $<$ LOD & \\
\hline 002 & 14.8 & $(<$ LOD-30.0) & $<\mathrm{LOD}$ & & n.a. & & n.a. & \\
\hline 003 & 31.0 & $(7.0-40.0)$ & 0.70 & $(<$ LOD- 0.70$)$ & n.a. & & n.a. & \\
\hline 004 & 14.0 & $(<$ LOD-35.0) & $<$ LOD & $(<$ LOD- 0.70$)$ & n.a. & & n.a. & \\
\hline 005 & 30.6 & $(<$ LOD-35.0) & $<\mathrm{LOD}$ & $(<$ LOD -0.70$)$ & n.a. & & n.a. & \\
\hline 006 & 50.0 & $(28.0-70.0)$ & $<$ LOD & & $<$ LOD & $(<$ LOD-5.0) & 2.25 & $(<$ LOD-6.00) \\
\hline 007 & 58.3 & $(27.0-93.0)$ & 0.89 & $(<$ LOD -2.50$)$ & 75.0 & $(60.0-100.0)$ & $<\mathrm{LOD}$ & $(<$ LOD -0.50$)$ \\
\hline 008 & 52.1 & $(<$ LOD-95.0) & $<$ LOD & $(<$ LOD -0.70$)$ & 40.3 & $(<$ LOD-90.0) & 0.50 & $(<$ LOD -1.80$)$ \\
\hline 009 & 48.6 & $(<$ LOD-92.0) & $<$ LOD & & 26.0 & $(<$ LOD -110.0$)$ & $<0.50$ & $(<$ LOD -0.50$)$ \\
\hline 010 & 36.8 & $(<$ LOD-70.0) & 0.70 & $(<$ LOD -0.70$)$ & 21.5 & $(<$ LOD-33.0) & $<0.50$ & \\
\hline 017 & n.a. & & n.a. & & 10.0 & $(<$ LOD-25.0) & 2.40 & $(<$ LOD -4.00$)$ \\
\hline 0041 & $<\mathrm{LOD}$ & & $<\mathrm{LOD}$ & $(<$ LOD -0.70$)$ & 65.0 & $(30.0-100.0)$ & $<0.50$ & \\
\hline 0081 & 95.0 & $(70.0-120.0)$ & 1.43 & $(<\mathrm{LOD}-2.50)$ & 77.9 & $(<$ LOD-147.0) & 1.20 & $(<$ LOD -4.00$)$ \\
\hline 0101 & 24.5 & $(7.0-42.0)$ & $<$ LOD & $(<$ LOD -0.70$)$ & 11.8 & $(<$ LOD-21.0) & 0.40 & $(<$ LOD -0.50$)$ \\
\hline$\%$ FREC & & 92.0 & & 31.0 & & 90.0 & & 50.0 \\
\hline$\% \mathrm{INC}$ & & 64.0 & & 36.0 & & 78.0 & & 33.0 \\
\hline
\end{tabular}




\begin{tabular}{|c|c|c|c|c|c|c|c|c|c|c|c|c|c|c|c|c|}
\hline \multirow{3}{*}{$\begin{array}{c}\text { Water body } \\
001 \\
002\end{array}$} & \multicolumn{2}{|c|}{ Anthracene } & \multicolumn{2}{|c|}{ Benzo(a)pyrene } & \multicolumn{2}{|c|}{ Benzo(ghi)perylene } & \multicolumn{2}{|c|}{ Benzo(b)fluoranthene } & \multicolumn{2}{|c|}{ Benzo(k)fluoranthene } & \multicolumn{2}{|c|}{ Dibenzo(a.h)anthracene } & \multicolumn{2}{|c|}{ Fluoranthene } & \multicolumn{2}{|c|}{ Benzo(a)anthracene } \\
\hline & $<$ LOD & $(<$ LOD-0.01) & $<\mathrm{LOD}$ & $(<$ LOD-0.06) & 0.06 & $(<$ LOD-0.15) & $<\mathrm{LOD}$ & $(<$ LOD-0.10) & $<\mathrm{LOD}$ & $(<$ LOD-0.60) & $<\mathrm{LOD}$ & $(<$ LOD-0.60) & 0.08 & $(<$ LOD-0.24) & 0.05 & $(<$ LOD-0.15) \\
\hline & $<$ LOD & & $<$ LOD & & $<\mathrm{LOD}$ & & $<$ LOD & & $<$ LOD & & $<\mathrm{LOD}$ & & $<\mathrm{LOD}$ & & $<$ LOD & \\
\hline 003 & $<$ LOD & & $<$ LOD & & $<$ LOD & & $<$ LOD & & $<$ LOD & & $<\mathrm{LOD}$ & & $<$ LOD & & $<$ LOD & \\
\hline 004 & $<$ LOD & $(<$ LOD- 0.01$)$ & $<$ LOD & $(<$ LOD-0.06) & $<$ LOD & $(<$ LOD-0.06) & 0.09 & $(<$ LOD- 0.20$)$ & $<$ LOD & $(<$ LOD-0.08) & 0.14 & $(<$ LOD-0.35) & 0.14 & $(<0.06-0.35)$ & 0.09 & $(<$ LOD-0.22) \\
\hline 005 & 0.03 & $(<$ LOD-0.09) & $<$ LOD & $(<$ LOD-0.06) & $<$ LOD & $(<$ LOD-0.06) & 0.07 & $(<$ LOD-0.18) & $<$ LOD & $(<$ LOD-0.06) & 0.06 & $(<$ LOD-0.13) & 0.22 & $(<0.06-0.80)$ & 0.10 & $(<$ LOD-0.35) \\
\hline 006 & 0.60 & $(0.42-0.90)$ & 0.70 & $(0.40-1.10)$ & 1.00 & $(0.73-1.45)$ & 3.40 & $(2.15-4.20)$ & 1.80 & $(1.15-2.45)$ & 0.35 & $(0.20-0.62)$ & NA & & 1.10 & $(0.85-1.35)$ \\
\hline 007 & 0.10 & $(0.01-0.24)$ & 0.45 & $(0.20-0.60)$ & 0.39 & $(0.14-0.60)$ & 1.25 & $(0.80-1.50)$ & 0.83 & $(0.50-1.30)$ & 0.72 & $(0.15-2.20)$ & 1.90 & $(0.70-3.50)$ & 0.66 & $(0.30-1.10)$ \\
\hline 008 & 0.04 & $(<$ LOD-0.1) & 0.08 & $(<$ LOD-0.10) & 0.08 & $(<0.06-0.16)$ & 0.25 & $(<$ LOD- 0.40$)$ & 0.15 & $(<$ LOD- 0.21$)$ & 0.20 & $(<$ LOD- 0.40$)$ & 0.63 & $(<$ LOD-1.50) & 0.17 & $(<$ LOD- 0.4$)$ \\
\hline 009 & 0.03 & $(0.01-0.1)$ & 0.21 & $(0.09-0.30)$ & 0.16 & $(0.06-0.30)$ & 0.48 & $(0.23-0.80)$ & 0.24 & $(0.12-0.31)$ & 0.22 & $(0.06-0.60)$ & 1.13 & $(0.3-2.0)$ & 0.37 & $(0.20-0.60)$ \\
\hline 010 & 0.04 & $(<$ LOD-0.07) & 0.14 & $(<$ LOD- 0.25$)$ & 0.11 & $(<0.06-0.19)$ & 0.42 & $(<$ LOD-0.80) & 0.22 & $(<$ LOD- 0.40$)$ & 0.67 & $(<$ LOD-1.30) & 0.37 & $(<$ LOD-0.70) & 0.56 & $(<$ LOD-1.10) \\
\hline 017 & n.a. & & n.a. & & n.a. & & n.a. & & n.a. & & n.a. & & n.a. & & n.a. & \\
\hline 0041 & 0.02 & $(<$ LOD-0.03) & 0.07 & $(<$ LOD-0.11) & 0.12 & $(<0.06-0.20)$ & 0.27 & $(<$ LOD- 0.50$)$ & 0.13 & $(<$ LOD- 0.22$)$ & 0.27 & $(<$ LOD-0.50) & 0.17 & $(<$ LOD-0.30) & 0.21 & $(<$ LOD-0.40) \\
\hline 0081 & $<$ LOD & $(<$ LOD -0.01$)$ & $<$ LOD & $(<$ LOD-0.06) & 0.06 & $(<0.06-0.08)$ & 0.32 & $(<$ LOD-0.60) & 0.12 & $(<$ LOD- 0.21$)$ & 0.14 & $(<$ LOD-0.25) & 0.22 & $(<$ LOD-0.40) & 0.31 & $(<$ LOD-0.60) \\
\hline 0101 & 0.05 & $(<$ LOD-0.10) & 0.27 & $(0.03-0.50)$ & 0.22 & $(<$ LOD- 0.40$)$ & 0.77 & $(<$ LOD-1.50) & 0.37 & $(<$ LOD- 0.70$)$ & 0.67 & $(<$ LOD-1.30) & 0.62 & $(<$ LOD-1.20) & 0.66 & $(<$ LOD-1.30) \\
\hline$\%$ FREC & & 62.0 & & 53.8 & & 69.2 & & 76.9 & & 61.5 & & 6.9 & & 83.3 & & 84.6 \\
\hline$\% \mathrm{INC}$ & & 58.3 & & 66.7 & & 58.3 & & 66.7 & & 75.0 & & 3.3 & & 58.3 & & 83.3 \\
\hline
\end{tabular}

\begin{tabular}{|c|c|c|c|c|c|c|c|c|c|c|c|c|c|c|c|c|}
\hline \multicolumn{17}{|l|}{ (a) Mussels } \\
\hline \multirow{2}{*}{$\frac{\text { Water body }}{001}$} & \multicolumn{2}{|c|}{ Anthracene } & \multicolumn{2}{|c|}{ Benzo(a)pyrene } & \multicolumn{2}{|c|}{ Benzo(ghi)perylene } & \multicolumn{2}{|c|}{ Benzo(b)fluoranthene } & \multicolumn{2}{|c|}{ Benzo(k)fluoranthene } & \multicolumn{2}{|c|}{ Dibenzo(a.h)anthracene } & \multicolumn{2}{|c|}{ Fluoranthene } & \multicolumn{2}{|c|}{ Benzo(a)anthracene } \\
\hline & 0.050 & $(0.029-0.085)$ & 0.045 & $(<$ LOD-0.085) & 0.045 & $(<$ LOD-0.060) & 0.250 & $(0.045-0.380)$ & 0.045 & $(<$ LOD-0.980) & 0.400 & $(0.150-0.550)$ & 0.900 & $(0.580-1.700)$ & 0.330 & $(0.093-0.550)$ \\
\hline 002 & n.a. & & n.a. & & n.a. & & n.a. & & n.a. & & n.a. & & n.a. & & n.a. & \\
\hline 003 & n.a. & & n.a. & & n.a. & & n.a. & & n.a. & & n.a. & & n.a. & & n.a. & \\
\hline 004 & n.a. & & n.a. & & n.a. & & n.a. & & n.a. & & n.a. & & n.a. & & n.a. & \\
\hline 005 & n.a. & & n.a. & & n.a. & & n.a. & & n.a. & & n.a. & & n.a. & & n.a. & \\
\hline 006 & 0.056 & $(0.019-0.090)$ & 0.633 & $(0.600-0.700)$ & 0.557 & $(0.170-0.900)$ & 1.733 & $(1.300-2.300)$ & 1.200 & $(0.800-1.800)$ & 1.047 & $(0.300-2.500)$ & 1.267 & $(0.900-1.600)$ & 0.383 & $(0.160-0.800)$ \\
\hline 007 & 0.251 & $(0.025-0.700)$ & 0.800 & $(0.300-1.600)$ & 0.900 & $(0.600-1.400)$ & 1.800 & $(0.800-2.700)$ & 1.250 & $(0.500-1.900)$ & 2.425 & $(0.200-6.000)$ & 1.750 & $(1.000-2.500)$ & 0.915 & $(0.110-2.500)$ \\
\hline 008 & 0.015 & $(<$ LOD-0.040) & 0.055 & $(<$ LOD-0.300) & 0.075 & $(<$ LOD- 0.170$)$ & 0.156 & $(<$ LOD-0.400) & 0.085 & $(<\mathrm{LOD}-0.230)$ & 0.223 & $(<$ LOD-0.600) & 0.181 & $(<$ LOD- 0.500$)$ & 0.119 & $(<$ LOD-0.310) \\
\hline 009 & 0.021 & $(<$ LOD-0.040) & 0.077 & $(<$ LOD- 0.200$)$ & 0.098 & $(<$ LOD- 0.300$)$ & 0.187 & $(<$ LOD-0.600) & 0.109 & $(<$ LOD-0.310) & 0.364 & $(<$ LOD-1.200) & 0.299 & $(<$ LOD-0.600) & 0.119 & $(<$ LOD-0.380) \\
\hline 010 & 0.025 & $(<$ LOD-0.040) & 0.118 & $(<$ LOD-0.200) & 0.134 & $(<$ LOD-0.210) & 0.284 & $(<$ LOD-0.500) & 0.154 & $(<$ LOD-0.270) & 0.774 & $(<$ LOD-1.400) & 0.258 & $(<$ LOD-0.440) & 0.275 & $(<$ LOD-0.500) \\
\hline 017 & 0.045 & $(0.030-0.040)$ & 0.045 & $(<$ LOD-0.045) & 0.045 & $(<$ LOD-0.045) & 0.079 & $(<$ LOD-0.170) & 0.045 & $(0.045-0.065)$ & 0.108 & $(0.045-0.170)$ & 0.360 & $(0.220-0.500)$ & 0.100 & $(0.030-0.170)$ \\
\hline 0041 & $<$ LOD & $(<$ LOD-0.008) & $<$ LOD & $(<$ LOD-0.045) & $<$ LOD & $(<$ LOD-0.045) & 0.096 & $(<$ LOD-0.170) & $<\mathrm{LOD}$ & $(<$ LOD-0.045) & 0.096 & $(<$ LOD-0.170) & 0.034 & $(<$ LOD-0.045) & 0.093 & $(<$ LOD-0.170) \\
\hline 0081 & 0.062 & $(0.008-0.110)$ & 0.201 & $(0.045-0.400)$ & 0.237 & $(0.045-0.330)$ & 0.506 & $(0.170-0.900)$ & 0.309 & $(0.045-0.600)$ & 0.343 & $(0.045-1.200)$ & 0.922 & $(0.310-1.800)$ & 0.222 & $(0.070-0.600)$ \\
\hline 0101 & 0.027 & $(<$ LOD-0.050) & 0.126 & $(<$ LOD-0.230) & 0.121 & $(<$ LOD-0.220) & 0.311 & $(<$ LOD-0.600) & 0.186 & $(<$ LOD-0.350) & 0.611 & $(<$ LOD-1.200) & 0.311 & $(<$ LOD-0.600) & 0.308 & $(<$ LOD-0.600) \\
\hline$\%$ FREC & & 90.0 & & 90.0 & & 90.0 & & 100.0 & & 90.0 & & & & 100.0 & & 100.0 \\
\hline$\%$ INC & & 66.7 & & 77.8 & & 66.7 & & 100.0 & & 88.9 & & & & 66.7 & & 100.0 \\
\hline
\end{tabular}

(b) Clams

Table 2. Concentrations of PAH in (a) mussel and (b) clam samples ( $\mu \mathrm{g} / \mathrm{kg}$ w.w.). Mean value, $\min -\max$ in brackets, n.a.: Samples Not Available, LOD: detection limit, \%FREC: percentage of the studied areas in which the pollutant is detected, \%INC: percentage of the studied areas where an increase of the contaminant took place from 2006 to 2007. 
Table 3. Ecotoxicological assessment criteria for PAHs in mussels (OPSAR, 2000) and equivalence factors to convert carcinogenic PAHs to total Benzo(a)pyrene equivalents (Gilroy, 2000).

\begin{tabular}{lcc}
\hline PAH & $\begin{array}{l}\text { Concentration in mussels } \\
\text { (mg/kg d.w.) }\end{array}$ & $\begin{array}{c}\text { Benzo(a)pyrene } \\
\text { equivalents }\end{array}$ \\
\hline Naphthalene & $0.5-5$ & - \\
Phenanthrene & $5-50$ & - \\
Anthracene & $0.005-0.05$ & - \\
Fluoranthene & $1-10$ & 0.020 \\
Pyrene & $1-10$ & 0.130 \\
Benzo(a)anthracene & - & 0.014 \\
Chrysene & - & 0.013 \\
Benzo(b)fluoranthene & - & 0.110 \\
Benzo(k)fluoranthene & - & 0.070 \\
Benzo(a)pyrene & $5-50$ & 1.000 \\
Indeno(1,2,3-cd)pyrene & - & 0.250 \\
Dibenzo(a,h)anthracene & - & 1.050 \\
Benzo(g,h,i)perylene & - & 0.030 \\
\hline
\end{tabular}




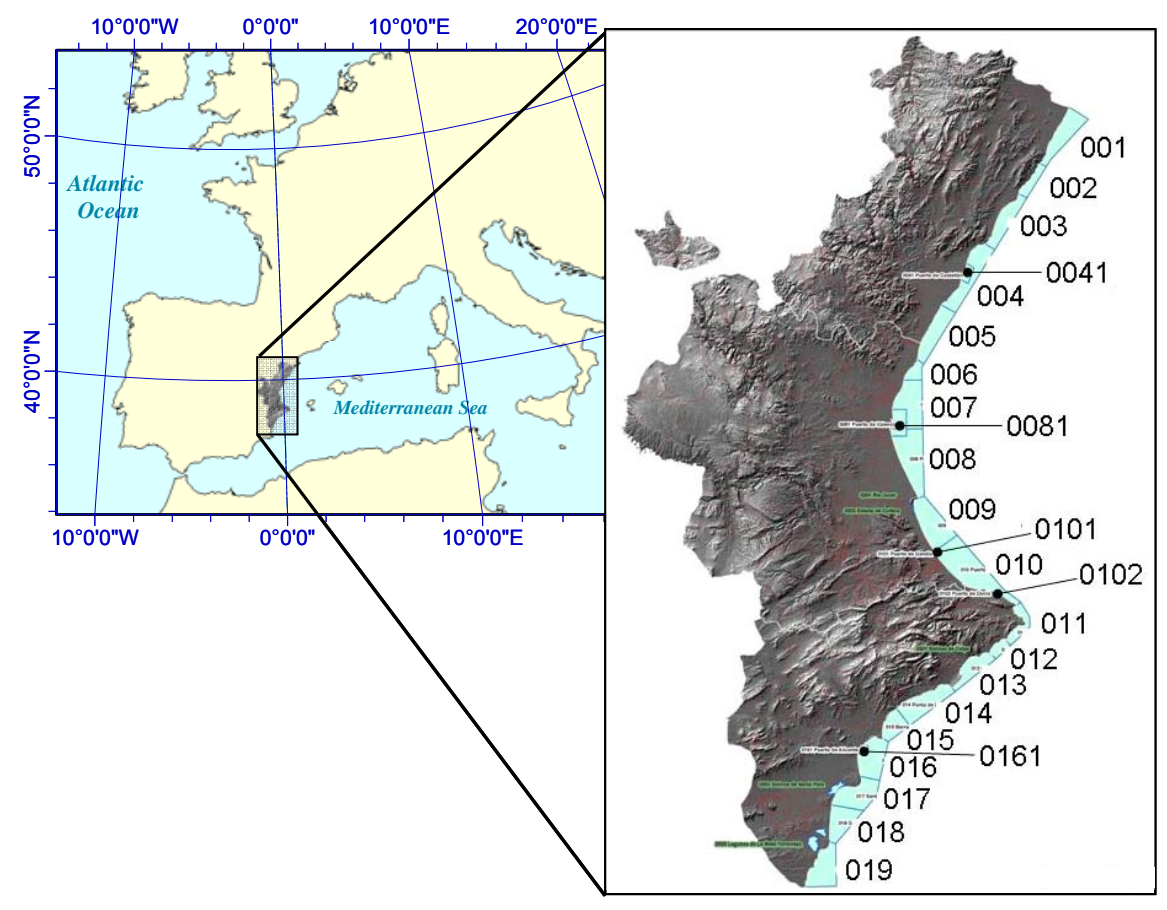

\begin{tabular}{|l|l|}
\hline \multicolumn{2}{|c|}{ COASTAL WATERS } \\
\hline CODE & \multicolumn{1}{|c|}{ DENOMINATION } \\
\hline 001 & Comunidad Valenciana boundary - Irta mountain range \\
\hline 002 & Irta mountain range \\
\hline 003 & Irta mountain range - Cape Oropesa \\
\hline 004 & Cape Oropesa - Burriana \\
\hline 005 & Burriana - Canet d'en Berenguer \\
\hline 007 & North coast of Valencia \\
\hline 008 & Port of Valencia - Cape Cullera \\
\hline 009 & Cape Cullera - Port of Gandia \\
\hline 010 & Port of Gandia - Cape San Antonio \\
\hline 011 & Cape San Antonio - Cape Moraira \\
\hline 012 & Cape Moraira - Rock of Ifach \\
\hline 013 & Rock of Ifach - Cape Les Caletes \\
\hline 014 & Cape Les Caletes - Cliff Aguas de Busot \\
\hline 015 & Cliff Aguas de Busot - Cape Huertas \\
\hline 016 & Cape Huertas - Santa Pola \\
\hline 017 & Santa Pola - Guardamar del Segura \\
\hline 018 & Guardamar del Segura- Cape Cervera \\
\hline 019 & Cape Cervera - Comunidad Valenciana boundary \\
\hline \multicolumn{2}{|c|}{ HEAVILY MODIFIED COASTAL WATERS } \\
\hline CODE & Port of Castellón \\
\hline 0041 & DENOMINATION \\
\hline 006 & Port of Sagunto \\
\hline 0081 & Port of Valencia \\
\hline 0101 & Port of Gandia \\
\hline 0102 & Port of Denia \\
\hline 0161 & Port of Alicante \\
\hline
\end{tabular}

Figure 1. Location of the 24 water bodies defined along the Comunidad Valenciana coast. (In the table, areas shaded in grey indicate areas were samples were not available) 


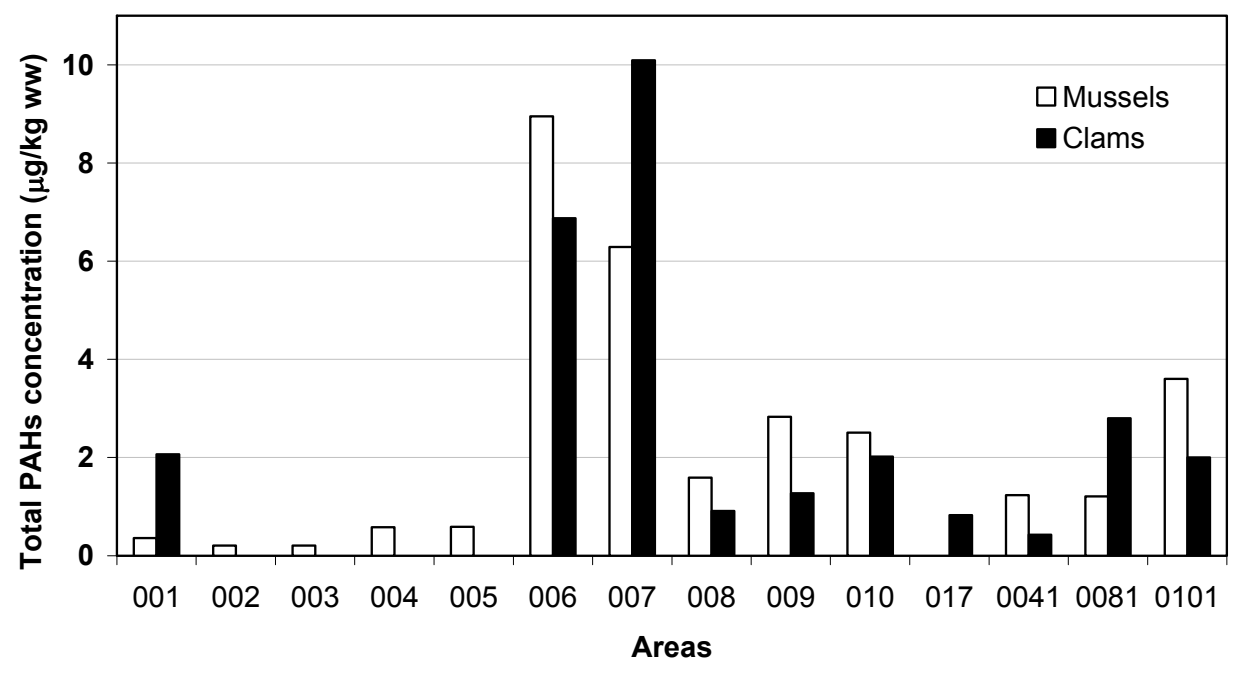

Figure 2. Total PAHs concentration (i.e, sum of the 8 measured PAHs) for mussels and clams $(\mu \mathrm{g} / \mathrm{kg} \mathrm{ww})$ in each water body.

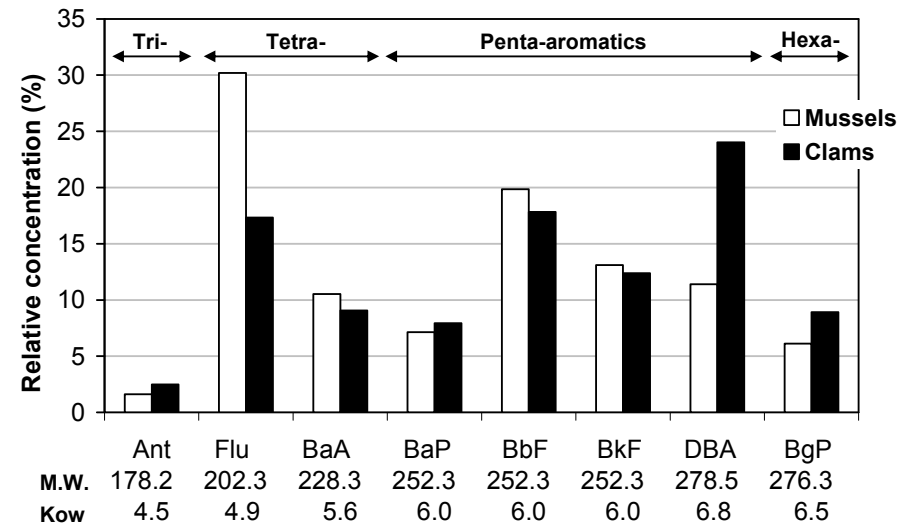

(a)

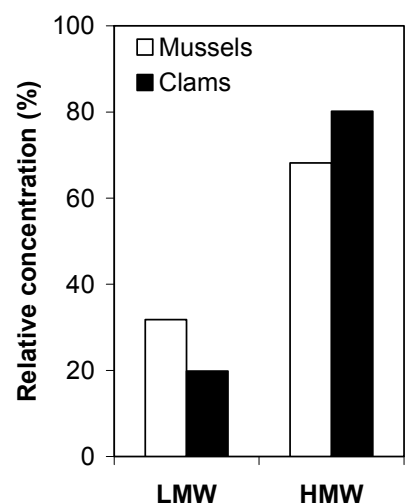

(b)

Figure 3. (a) Relative concentration of each PAH in bivalves from area 007. (b) Relative concentration of High and Low Molecular Weight PAHs in area 007. In this figure M.W. stands for Molecular Weight; LMW for Low Molecular Weight and HMW for High Molecular Weight. 


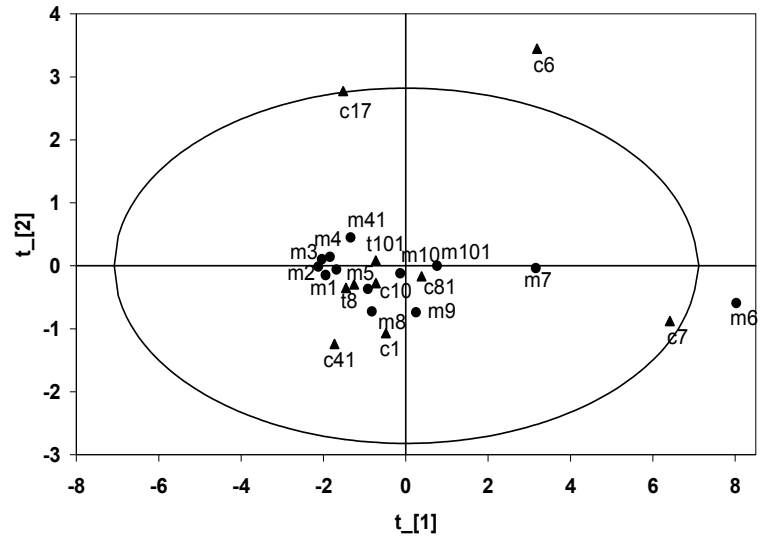

(a)

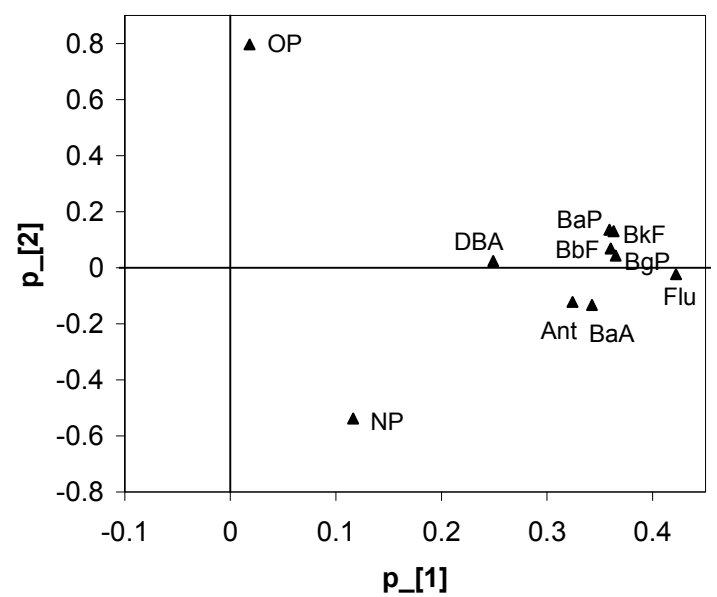

(c)

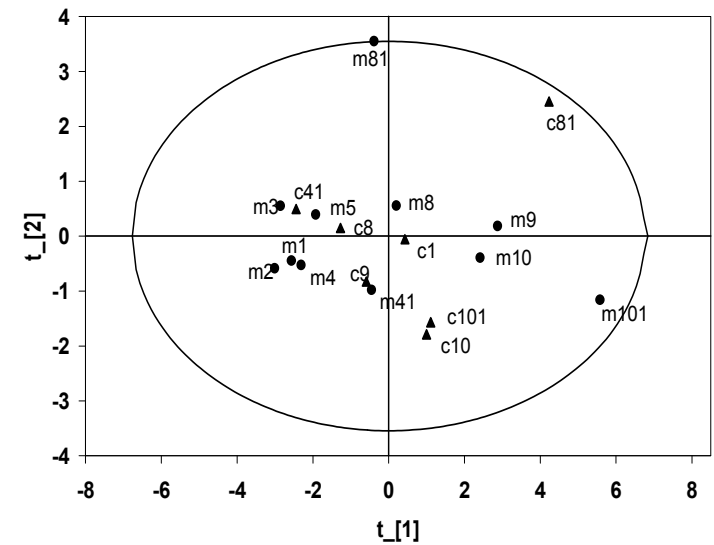

(b)

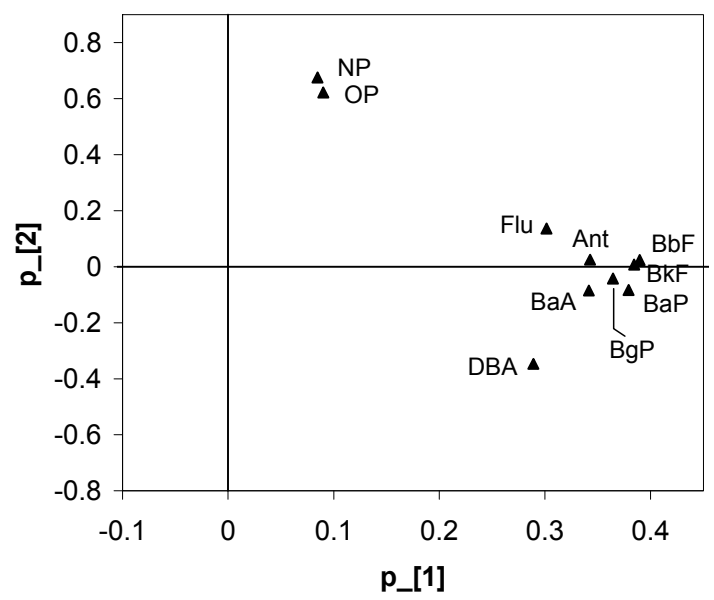

(d)

Figure 4. (a), (c) PCA-scores and loadings for the analysis including all areas. (b), (d) PCA-scores and loadings for the analysis excluding areas 006, 007 and 017 . In the scoreplots, "c" stands for clams, "m" for mussels, and the number refers to the water body (e.g., c6: clams in area 006). In the loading plots, OP: octylphenol; NP: nonylphenol; Ant: anthracene; BaP: benzo(a)pyrene; $\mathrm{BgP}$ : benzo(g,h,i)perylene; $\mathrm{BbF}$ : benzo(b)fluoranthene, BkF: benzo(k)fluoranthene; DBA: dibenzo(a,h)anthracene; Flu: fluoranthene; BaA: benzo(a)anthracene. 